\title{
Sweet cassava cooking time
}

\author{
Lilian Azevedo Miranda ${ }^{1}{ }^{(}$, Wilma Aparecida Spinosa ${ }^{1}$, Tainá Miranda Destro ${ }^{1, *}{ }^{\circ}$, Helio de \\ Souza Junior ${ }^{2, *}$ and Vagner do Nascimento ${ }^{3, *}$
}

\begin{abstract}
${ }^{1}$ Universidade Estadual de Londrina (UEL), Centro de Ciências Agrárias (CCA-TAM) - Rodovia Celso Garcia Cid, Km 380, s/n - Campus Universitário, CEP 86057-970, Londrina, PR, Brazil. ' Universidade Norte do Paraná (UNOPAR), Setor de Agronomia, Avenida Paris, 675, Jardim Piza, CEP 86041-140, Londrina, PR, Brazil. 3Universidade Estadual Paulista (UNESP) "Júlio de Mesquita Filho", Faculdade de Ciências Agrárias e Tecnológicas (FCAT), Campus de Dracena, Rodovia Comandante João Ribeiro de Barros, Km 651, Bairro Das Antas, CEP 17900-000, Dracena, SP, Brazil. *Co-corresponding authors, E-mails: taina1987@gmail.com / helioszjr@gmail.com / vagnern@gmail.com
\end{abstract}

\begin{abstract}
Yield and culinary quality of tuberous cassava roots can be influenced by several factors such as genotype, soil fertility, cultural management, climatic conditions, harvest, handling and storage after harvest as well as cooking methods. For consumers, the most important characteristics for sweet cassava roots are how fast they are cooked and its taste. Thus, the objective of this research was to study the evolution of different methods to evaluate tuberous cassava roots cooking time that can be used by breeders. It is essential that statistical analyses are realized, in order to arrive to confident results. Other important observations are the cost and ease of application of the methodology and whether more sophisticated equipment is available. That is why we suggest the objective method using a cheap modified Matson's device, and equal weight sticks of tuber cassava central parts to be analyzed with three repetitions. Certainly, it is desirable an increase in carotenes, proteins, as well as yield, once for millions, sweet cassava is the main source of energy.
\end{abstract}

Keywords: Manihot esculenta Crantz, yuca, manioc, carbohydrates, culinary, sensory qualities, tuberous roots.

\section{INTRODUCTION}

Cassava (Manihot esculenta Crantz) is a perennial and shrub plant, belonging to Euphorbiaceae family. The genus Manihot, originated in Brazil (was the world-leading producer, 25 million t (Mt), in 1999) (Food and Agriculture Organization of the United Nations [FAO], 2000; Miranda, Spinosa, Destro, Souza-Junior, Nascimento, \& 2019). It was introduced in West Africa by Portuguese sailors in the sixteenth century. Then it expanded throughout the tropics, between latitudes $30^{\circ} \mathrm{N}$ and $30^{\circ} \mathrm{S}$, from sea level to above $2000 \mathrm{~m}$ altitude. Cassava is the main source of carbohydrates for more than 800 million people, especially in developing countries (FAO, 2013), where it is the most widely cultivated crop, contributing to food security. It is chosen mainly because: $a=$ it has vegetative propagation; $b=$ it needs limited input, so can be cultivated in areas with low fertility or problematic soils (high phosphorous fixation, erosion or high aluminum content); $c=$ its matured edible roots can be stored in ground for about three years; $d=$ is high pest and disease tolerant, and $\mathrm{e}=\mathrm{it}$ is drought-tolerant, so can be grown in areas with low and erratic precipitation of less than $600 \mathrm{~mm}$ annually, coupled with dry air and high temperatures (Alves \& Setter, 2000; Iyer, Mattinson, \& Fellman, 2010; Okogbenin et al., 2013; Guira et al., 2017).

The world cassava production was 278 million tonnes (Mt) in 2012 and, in 5 years, increased to $292 \mathrm{Mt}$, as fresh root equivalent. It is grown in over 90 countries. Sub-Saharan Africa (around 40 countries) contributes with $61 \%$, followed by Asia (29.5\%) and Americas (9.5\%). Nigeria was the largest producer with $59.5 \mathrm{Mt}$, followed by Congo (31.6 Mt), Thailand (31 Mt), Indonesia (19 Mt), Brazil (18.9 Mt) and Ghana (18.5 Mt). Cassava, also known as yuca or manioc, is crucial to food security in parts of Africa, Asia and South America. But the level of edible starch varies with cultivar, geography and climate, as does the presence of a blight known as cassava mosaic disease (Figure 1). Thailand was the highest cassava exporter (US\$1.19 billion), with $54 \%$ share of the world's total value (Ferguson, Shah, Kulakow, \& Ceballos, 2019; Maxmen, 2019; Otekunrin \& Sawika, 2019).

The mean annual production of cassava worldwide is 10 t.ha $^{-1}$. But they are lower in Africa (8.8) compared to both South America (12.8) and Asia (21.9). This is due to many reasons, including limited adoption of improved varieties, suboptimal agronomic practices, viral diseases, and other biotic and abiotic 
stress conditions (Ferguson et al., 2019).

Minimizing tillage to protect soil health, optimizing timing and methods of planting, using biological control agents to counter pests and diseases, well-balanced applications of mineral fertilizer, in combination with intercropping, crop rotation, cultivars adapted to the place, mulching, manure and compost, can make a cassava-based farming system more productive, profitable, and more sustainable (FAO, 2013). The Next Generation Cassava Breeding project aims to accelerate the creation of more resilient cassava cultivars, and improve yields, by using genetic sequencing to identify advantageous hybrids. They will screen the resulting offspring for genetic markers used to predict a plant's resistance to mosaic viruses, along with 12 other traits, such as the amount of edible starch (Maxmen, 2019). The global cassava market is projected to register an increasing compound annual growth rate (CAGR), that may achieve a growth rate of 3.2\% from 2019 to 2024, reaching a market value of US\$ 4.5 billion by the end of 2024 (Market Research Future, 2020).

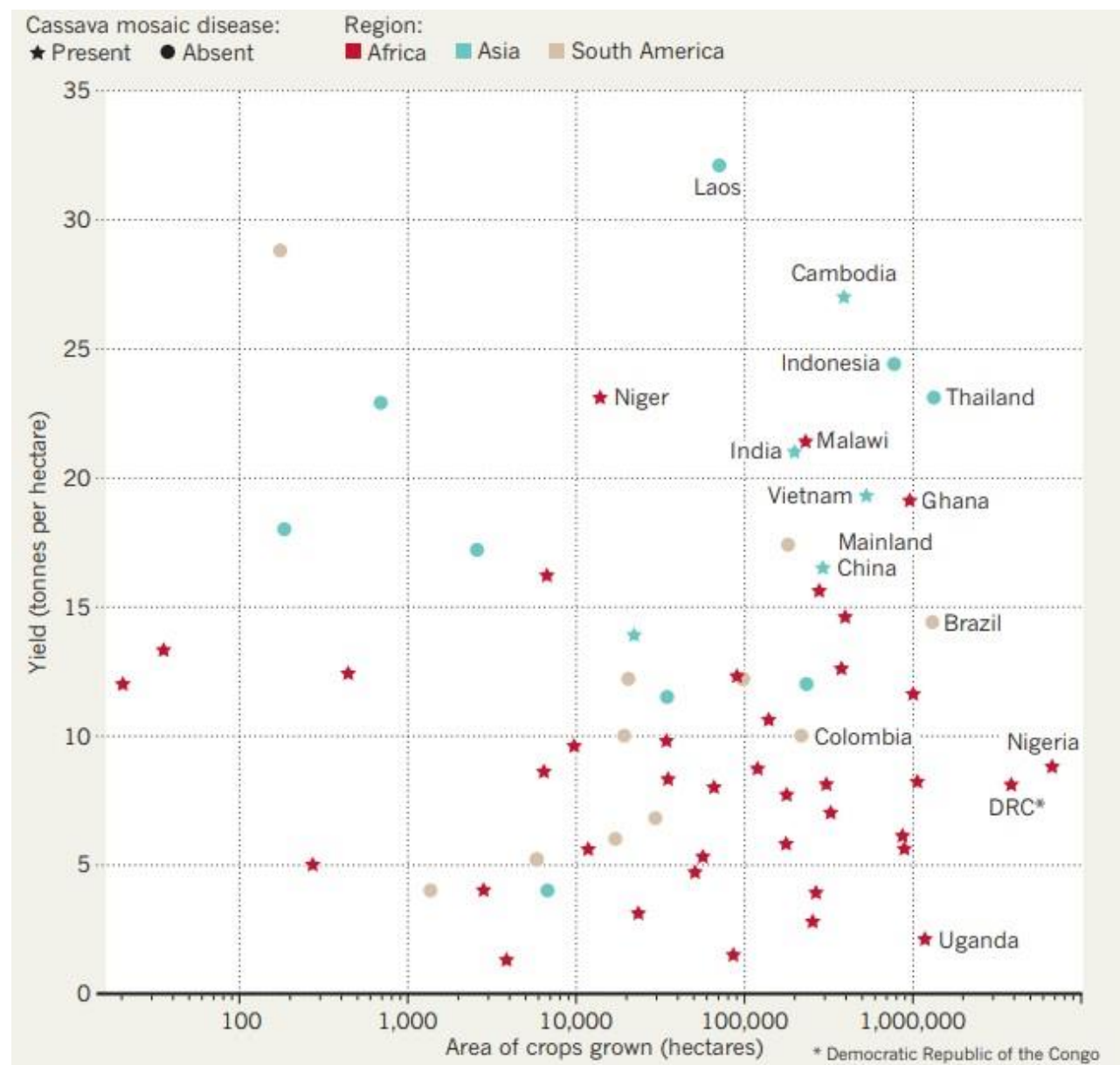

Figure 1. Area grown with cassava (ha) per country and its yield (tons per ha) (Maxmen, 2019).

The majority of Africa's population, as well as Latin America and Asia depends on cassava for sustenance as it is consumed directly as food for farmers and their animals, or it is processed at the farms, or by industries. Cassava roots consumption depends on the country, season and world trade: raw (Kenia), fermented, cooked, fried, processed products (chips, flour, starch, sweeteners, glue, etc.), animal feed, edible substitute for plastic packaging, paper, textile, pharmaceutical industries or ethanol (Githunguri, 1995; Balagopalan, 2002; Favaro, Beléia, Fonseca-Junior, \& Waldron, 2008; FAO, 2018; Otekunrin \& Sawicka, 2019).

\section{CASSAVA AS FOOD}

Approximately 500 million people depend on cassava tuberous roots as a major energy source and more than 70 million people obtain about $500 \mathrm{kcal}$ daily from it. Cassava is grown predominantly by small-scale farmers with limited resources, in part because it yields more energy per hectare than other major crops. Cassava produces $1,045 \mathrm{~kJ} / \mathrm{ha}$, maize 836 , rice 652 , wheat 460 , and banana 334 . So, it is fundamental as food security for rural communities (Chávez et al., 2005; Montagnac, Davis, \& Tanumihardjo, 2009.). That's 
why their nutritional factors are particularly important, like higher protein, carotene and mineral contents, as well as lower level of cyanogens (less than $100 \mathrm{mg} \cdot \mathrm{kg}^{-1}$ ). Other desirable properties are high yields, pleasant sensory qualities (softness and plasticity after cooking, non-sticky mass, aroma and pleasant appearance); good culinary properties (low fiber content, short cooking time and homogeneous mass after cooking); desirable architecture for cultivation (fewer and higher branches); resistance to pests and diseases; among other characteristics (Vieira et al., 2018).

Cassava leaves are a significant source of protein for both humans and animals. They are rich in proteins (good profile of essential amino acids, such as methionine, cysteine, and cystine), as well as carotenes, vitamins, minerals and fibers. Leaves from twelve cultivars of cassava were collected and total protein percentage ranged from 11.81 to 22.75 (Popoola et al., 2019). However, it has high levels of anti-nutritional and toxic substances, such as cyanogenic glycosides, tannin and phytin. Toxicity problems can be reduced by traditional preparation methods such as drying (Sun-drying is considered inexpensive), pounding and long periods of boiling (Reyes, Snow, \& Rodd, 2018; Oresegun, Fagbenro, llona, \& Bernard, 2016).

Tuberous cassava roots (Figure 2) are formed by periderm, a thin layer of cells which comprises approximately $3 \%$ of the total weight of the root; cortex, with three different layers: cortical parenchyma, sclerenchyma and phloem cells, $11-20 \%$ of the root weight and parenchyma, the edible portion (77-86\%), with xylem vessels, radially distributed in a matrix of starch containing cells (Odoemelam et al., 2020). Roots from different cultivars, showed moisture content (33.14-45.86\%), protein (1.17-3.48\%), ash (1.71-2.34\%), fat $(0.74-1.49 \%)$ and carbohydrate (83.42-87.35\%) (Table 1). The carbohydrate starch content, ranges from 64 to $72 \%$ (amylose and amylopectin) which is structurally different from that found in cereals; 17\% of sucrose (predominantly in sweet varieties); small quantities of fructose and dextrose; and crude fiber (1.388.31\%). Mineral contents were 0.60-1.60, 1.35-1.58, 1.06-2.13, 0.16-0.24, 0.021-0.030, 0.04-0.13, 0.25-0.36 and 0.25-0.37 mg.100 $\mathrm{g}^{-1}$ for $\mathrm{Ca}, \mathrm{Mg}, \mathrm{P}, \mathrm{Fe}, \mathrm{Mn}, \mathrm{Zn}, \mathrm{K}$ and Na, respectively (Afoakwa, Asiedu, Budu, ChiwonaKarltun, \& Nyirendah, 2012; Chávez et al., 2005). Roots have levels of 0.1-1.04 mg.100 $\mathrm{g}^{-1}$ and 0-37.5 mg.100 $\mathrm{g}^{-1}$ for carotene and ascorbic acid, respectively (Morante et al., 2010) plus vitamin C, thiamine, folate, riboflavin, and niacin (Market Research Future, 2020).

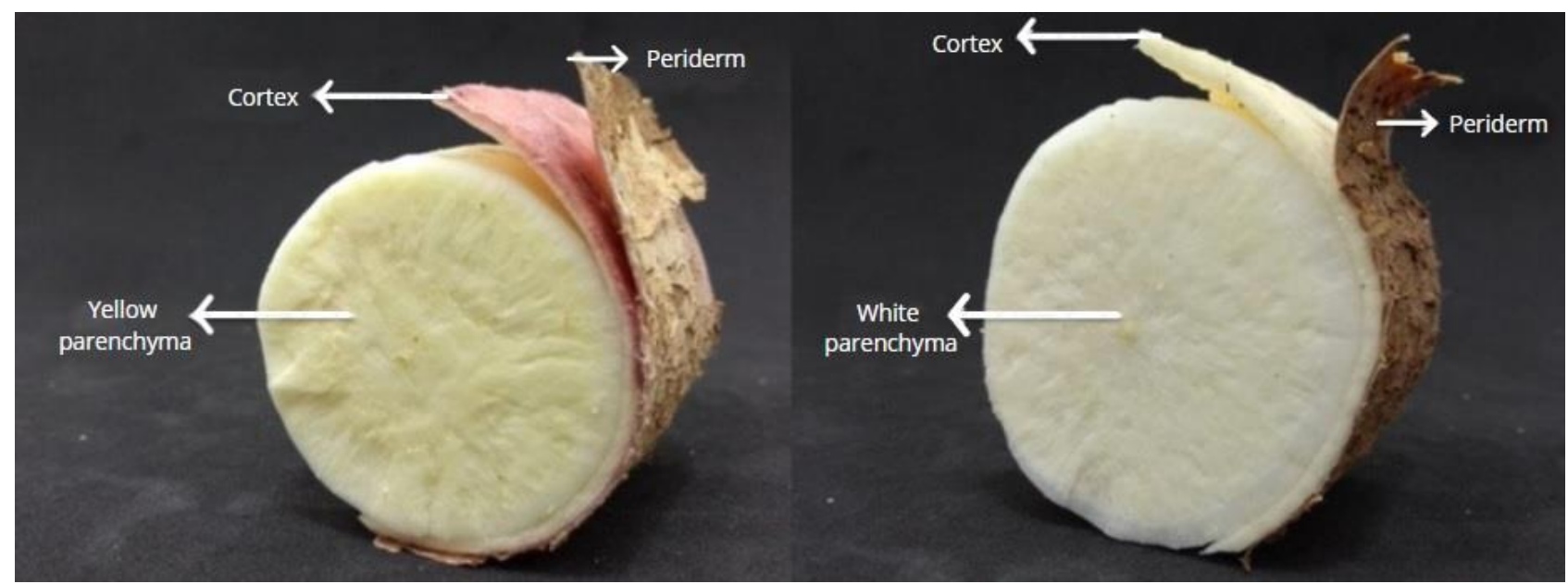

Figure 2. Crosssections from raw cassava roots (Adapted from Pedri et al., 2018).

Jarvis, Ramirez-Villegas, Campo and Navarro-Racines (2012) examining the impacts that climate change will likely have on cassava and on other important staple food crops for Africa, including maize, millets, sorghum, banana, and beans, based on projections to 2030, concluded that cassava is potentially highly resilient to future climatic changes.

\section{CONSTRAINTS}

Commercial production of sweet cassava faces some constraints, such as short shelf life, low protein content, the presence of potentially toxic levels of cyanogenic glycosides and susceptibility to the African Cassava Mosaic Virus (ACMV) (Salcedo \& Siritunga, 2011; Andrade \& Laranjeira, 2019).

\section{Short shelf life}

Short shelf life severely limits the marketing options by increasing losses and the overall marketing costs. 
Post-harvest losses due to postharvest physiological deterioration (PPD), are estimated to be as high as 30\% in sub-Saharan Africa (Djabou, Carvalho, Li, Niemenak, \& Chen, 2017; Mtunguja, Beckles, Laswai, Ndunguru, \& Sinha, 2019). It is a consequence of physiological actions, that usually starts 24 hours after harvest, increasing the concentration of phenolic compounds, causing vascular streaking, which is a blue-black discoloration of the xylem parenchyma, followed by general discoloration of the storage parenchyma (Figure 3).

Table 1. Approximate composition of cassava roots and leaves (Montagnac, Davis, \& Tanumihardjo, 2009; Morante et al., 2010; Market Research Future, 2020).

\begin{tabular}{|c|c|c|}
\hline PROXIMATE COMPOSITION (100 g) & ROOTS & LEAVES \\
\hline Food energy (kcal) & $110-149$ & 91 \\
\hline Food energy (kJ) & $526-611$ & $209-251$ \\
\hline Moisture (g) & $33.1-85.3$ & $64.8-86.6$ \\
\hline Dry weight & $29.8-39.3$ & $19-28.3$ \\
\hline $\operatorname{Protein}(\mathrm{g})$ & $0.3-8.5$ & $1.0-10.0$ \\
\hline Lipid (g) & $0.03-0.5$ & $0.2-2.9$ \\
\hline Carbohydrate, total (g) & $25.3-35.7$ & $7-18.3$ \\
\hline Dietary fiber $(\mathrm{g})$ & $0.1-3.7$ & $0.5-10.0$ \\
\hline $\operatorname{Ash}(g)$ & $0.4-2.3$ & $0.7-4.5$ \\
\hline \multicolumn{3}{|l|}{ VITAMINS } \\
\hline Thiamin (mg) & $0.03-0.28$ & $0.06-0.31$ \\
\hline Riboflavin (mg) & $0.03-0.06$ & $0.21-0.74$ \\
\hline Niacin (mg) & $0.6-1.09$ & $1.3-2.8$ \\
\hline Ascorbic acid (mg) & $14.9-50$ & $60-370$ \\
\hline Vit A $(\mu \mathrm{g})$ & $5.0-35.0$ & $8300-11800$ \\
\hline \multicolumn{3}{|l|}{ MINERALS } \\
\hline Calcium $(\mathrm{mg})$ & $19-176$ & $34-708$ \\
\hline Phosphorous, total (mg) & $6-152$ & $27-211$ \\
\hline $\mathrm{Ca} / \mathrm{P}$ & $1.6-5.48$ & 2.5 \\
\hline Iron (mg) & $0.3-14.0$ & $0.0-8.3$ \\
\hline Potassium (g) & 0.25 & 0.35 \\
\hline Magnesium (g) & 0.03 & 0.12 \\
\hline Copper (ppm) & 6.0 & 12.0 \\
\hline Sodium (ppm) & 213.0 & 177.0 \\
\hline Manganese (ppm) & 10.0 & 252.0 \\
\hline
\end{tabular}

That resembles typical changes associated with the plant's response to wounding, and triggers a cascade of biochemical reactions, associated to reactive oxygen. The burst of reactive oxygen species (ROS) results in serious cell oxidative damage and is regulated by an antioxidant system including enzymatic and nonenzymatic scavenging mechanisms (Liu et al., 2019). These reactions release substances that favor the development of microorganisms, which start microbiological deterioration of the roots (Henrique, Prati, \& Sarmento, 2010; Morante et al., 2010).

Postharvest losses in cassava production in Latin America, Caribe and Asia reached about $9 \%$, whereas in Africa they reached 29\% (FAO, 2000). At the market chain, the economic losses due to price discount can reach up to $90 \%$ (Salcedo \& Siritunga, 2011).

The roots with high carotene content tend to suffer less from PPD (Sánchez et al., 2006; Morante et al., 2010; Pedri et al., 2018). Roots with amylose-free starch, showed less PPD. Dry matter content and PPD were positively correlated (Morante et al., 2010). Cassava slices sprayed with water and methyl jasmonate (MeJA), or melatonin or $\mathrm{CaCl}_{2}$ delayed deterioration rate. Keeping the cassava at $10{ }^{\circ} \mathrm{C}$ and $80 \%$ relative humidity could also delay PPD for 14 days (Liu et al., 2019). 


\section{2 h 24 h 36 h 48 h 72 h}
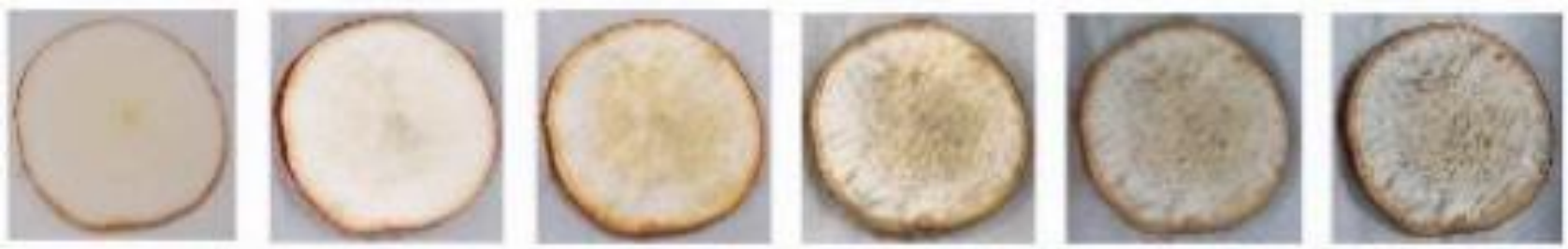

Figure 3. Postharvest physiological deterioration in cassava storage root slices (Liu et al., 2019).

The bioaccessibility of beta-carotene $(\mathrm{BC})$ of boiled cassava is highly correlated with its content on different cultivars (Thakkar, Huo, Maziya-Dixon, \& Failla, 2009). But other processing methods affect both $B C$ retention and bioaccessibility. Oven-drying, shadow drying and boiling retained the highest levels of BC (71.9, 59.2 and 55.7\%, respectively) and gari the lowest (about 34.1\%) (Chávez et al., 2007). Boiled roots retain $90 \% \mathrm{BC}$, but to prepare gari, for example, roasting fermented cassava at $195{ }^{\circ} \mathrm{C}$ for $20 \mathrm{~min}$, decreased $\mathrm{BC}$ content by $90 \%$. Retention was increased to $63 \%$ when temperature was decreased to $165^{\circ} \mathrm{C}$ and roasting was limited to $10 \mathrm{~min}$ (Thakkar et al., 2009). Eyinla, Maziya-Dixon, Alamu and Sanusi (2019) produced gari by fermentation for one and three days. The concentration of $\mathrm{BC}$ in fresh cassava tuberous roots ranged from 5.32 to $7.81 \mu \mathrm{g} / \mathrm{g}$. Final products showed retentions that ranged from 14.4 to $29.3 \%$ and 10 to $21.7 \%$ respectively. Some cultivars presented retention advantage over others, irrespective of the initial concentration in their fresh roots.

\section{Low protein content}

Chávez et al. (2005) studied 2,457 genotypes and observed that mean protein content was 3.56 with an mean standard deviation of 0.282 and a low coefficient of variation (8.72\%). There were 33 clones classified as high protein, showed 5.94 to $8.31 \mathrm{mg}$ per $100 \mathrm{~g}$ of crude protein. Araújo, Moura, Cunha, Farias-Neto and Silva (2019) studied Brazilian sweet and biter cassava cultivars and their protein content were 0.18-1.10 and 0.46-2.27, respectively. Yeoh and Truong (1996) studied how to determine protein contents of 15 cassava cultivars and concluded that three conversion factors could be used: $k_{A}, k_{A A}$ and $k_{P} . k_{P}$ is based on Kjeldahl nitrogen and ranged from 2.49 to 3.67. Therefore, a mean $k$, value of 3.24 should provide a better estimate of the protein content in cassava roots.

There is a broad class of Carotenoid-Associated Proteins (CAP) that are related to several cell functions, such as pro-plastid and plastid differentiation, chromoplast formation, chromoplast differentiation and carotenoid sequestration, especially in non-green tissue such as roots. Total buffer extractable protein (TBEP, mg per g, DWt) content variation in cassava storage root (CSR) was correlated with total carotenoid contents $\left(\mu \mathrm{g} \cdot \mathrm{g}^{-1} \mathrm{DWt}\right)$ and was differentially distributed in the storage root tissue compartments due to tissue age as the secondary growth proceeded (Carvalho, Anderson, Silva, Chen, \& Souza, 2019).

\section{Cyanogenic glycosides (HCN)}

As many as 12,000 plant species, including many important crops such as cassava, sorghum, almonds, lima beans and white clover contain cyanogenic glucosides (Narayanan, Ihemere, Ellery, \& Sayre, 2011). Roots and leaves of cassava contain three different forms of cyanogens: linamarin, lotaustralin and cyanide. Linamarin is stored in the vacuoles while the enzyme linamarase is found in the cell wall and laticifers (McMahon, White, \& Sayre, 1995). This compartmentalization means cyanogenesis occurs only during tissue disruption when the enzyme and substrate mix to yield cyanide and acetone. Cyanogenic glycosides are effective defense agents against generalist herbivores (Gleadow \& Woodrow, 2002), including humans, who may have headache, dizziness, confusion, tachypnea, tachycardia, mydriasis - seizures and coma can develop as it progresses-, apnea, hypotension, bradycardia and cardiac arrhythmia, that can lead to death, depending on the amount ingested and the individual's health status (Graham \& Traylor, 2019).

Popularly, cassava cultivars are classified into two variety groups: a) sweet, for table use: also known as aipim, macaxeira, tapioca (Brazil), yucca (Spanish), singkong (Thailand), mogo (Africa) manioc; and b) bitter, for industry: called wild cassava or mandioca brava. Bitter varieties tend to show as much as $1000 \mathrm{mg}$ of linamarin per $\mathrm{kg}$ of fresh roots. Sweet varieties show less than $100 \mathrm{mg} \cdot \mathrm{kg}^{-1}$ (Vieira et al., 2018). Sets of DNA or morphological markers can distinguish between these two groups. 
Principal component (PC) analysis was used to evaluate the most important descriptors to discriminate between 'sweet' and 'bitter' cassava. Sweet cultivars were located in the first 2 PCs, where sucrose and fructose showed the highest association (eigenvectors of 0.38 and -0.51 , respectively). Free and total cyanide were significantly associated with the first component (both eigenvectors 0.36 ). Ashes and total titratable acidity (TTA) were highly correlated with the third component, -0.53 and -0.52 , respectively, and total carotenoids (TC) was highly correlated with the fourth component (0.81) (Araújo et al., 2019).

Hydroxy Nitrile Lyase (HNL) in roots leads to: 1 ) reduced steady-state linamarin levels, 2) elevation of HNL protein levels and 3) a substantial reduction in cyanogen levels in processed cassava roots. Since HNL is localized in the apoplast, it presumably is not subject to proteolytic turnover in intact tissues. Thus, targeting a root storage protein to the apoplast is proposed to be an effective strategy to hyper-accumulate proteins in cassava roots. In addition, HNL has a well-balanced amino acid composition for human nutrition. Narayanan et al. (2011) immobilized a plasmid carrying cassava HNL cDNA into an Agrobacterium tumefaciens strain, by electroporation and used to transform cassava cultivar, through a friable embryogenic callus system. The resultant roots not only showed accelerated root cyanogenesis resulting in safer food products, but increased root protein concentrations by three-fold.

\section{Cooking Time}

Sweet cassava roots are usually eaten at home cooked, fried, as an ingredient of different dishes and in food industries (ready meals like croquettes, fried chips or snacks). Thus, appearance, shelf life, taste and cooking time are the most desirable characteristics. To make it safe for consumption, roots must be harvested, peeled, processed, and stocked properly. Differences in cooked cassava root textures were supposed to be influenced by several factors, such as: quantity and quality (chemical composition, physicochemical properties, morphology and molecular structure of starch, quantity and quality of other root components, the arrangement of starch granules in cells, the organization of cells, the arrangement of tissue in cassava root, etc.) (Charoenkul, Uttapap, Pathipanawat, \& Takeda, 2006).

The starch granule is a biopolymer consisting of chains of $\alpha-(1-4)$ linked D-glucose interlinked with $\alpha-(1-6)$ glycosidic linkages, creating branches. Amylose presents linear longer chains and amylopectin, short branched chains, that form double-helices, which are responsible for the crystallinity (Bertoft, 2017; Yu et al 2019). The amylose content classifies cassava starches into waxy (0-15\%), normal (20-35\%) and highamylose types (>40\%) (Chisenga, Workneh, Bultosa, \& Alimi, 2019).

The minor non-starch compounds in the starch granule include protein, lipid, fiber and phosphorus. These compounds allied with variations in starch granule (size, shape and distribution), degree of polymerization, amylose/amylopectin ratio and amylopectin's chain lengths, can affect the composition, gelatinization, paste properties, enzymatic susceptibility, crystallinity, swelling, and solubility (Charoenkul et al., 2006; Vasconcelos, Brito, Carmo, Oliveira, \& Oliveira, 2017; Yu et al. 2019). Lower amylopectin molecules have high solubility, what is associated with good cooking and eating qualities (Mufumbo et al., 2011, Yu et al., 2019). The amylopectins molecular size from easy cooking cultivars were much smaller than those of the other cultivars (Table 2). Crosssections from different kinds of cassava cooked roots are shown in Figure 4.

Heating starch in water results in disruption of hydrogen bonds and exposition of hydroxyl groups, consequently disruption of crystalline structure, what causes cell wall separation, thus generating an increase in cell volume. This process is called gelatinization. That results in solubility of starch, viscosity development and swelling (Chisenga et al., 2019). Cohesiveness of the tissue is affected by middle lamella pectin solubilization and cell separation as well as a gradual first order softening during cooking (Beléia, Prudencio-ferreira, Yamashita, Sakamoto, \& Ito, 2005). The extent of gelatinization of cassava roots was determined using an iodine colorimetric method and a generalized model for starch gelatinization was used to model the cooking process (Beleia, Butarelo, \& Silva, 2006).

Since cassava starch granule contain less lipids and proteins - which means less competition for water molecules - than corn, wheat and potato starches, these could explain its highest swelling power and solubility (Chisenga et al., 2019). It also shows too, enhanced resistance to acid treatments, permitting its use in the composition of unique pastes (Taylor, Fauquet, \& Tohme, 2012). Mtunguja et al. (2016) reported an inverse relationship between swelling power and amylose content in cassava starch. Enthalpy of gelatinization correlates positively with crystallinity, and negatively with long chain amylopectin starches. High short amylopectin chain length exhibited lower gelatinization temperature than long chain (Singh, Singh, Isono, \& Noda, 2010). It is also important to study the influence of non-starch components on starch functionality (Chisenga et al., 2019). 
Table 2. Molecular size and number of unit chains of cassava amylopectins and amyloses (Charoenkul et al., 2006).

\begin{tabular}{|c|c|c|c|c|c|c|c|c|}
\hline \multirow[t]{3}{*}{ SAMPLE } & \multicolumn{5}{|c|}{ AMYLOPECTINS $^{1}$} & \multicolumn{3}{|c|}{ AMYLOSES $^{2}$} \\
\hline & \multirow[t]{2}{*}{$\mathrm{NC}_{\mathrm{amp}}$} & \multicolumn{3}{|c|}{$\mathrm{NC}$ unit chain } & \multirow{2}{*}{$\begin{array}{l}\text { DP of } \\
\text { amylopectin }\end{array}$} & \multirow{2}{*}{$\begin{array}{l}\text { Chain } \\
\text { Lengh }\end{array}$} & \multirow{2}{*}{$\begin{array}{c}\text { Linear } \\
(\% \mathrm{~mol} / \mathrm{mol})\end{array}$} & \multirow{2}{*}{$\begin{array}{c}\text { Branched } \\
(\% \mathrm{~mol} / \mathrm{mol})\end{array}$} \\
\hline & & A & B1 & $\mathrm{B} 2+\mathbf{B} 3$ & & & & \\
\hline M & 300 & 189 & 78 & 33 & 6000 & 450 & 58 & 42 \\
\hline $\mathbf{F}$ & 855 & 530 & 231 & 94 & 17100 & 550 & 48 & 52 \\
\hline MF & 760 & 479 & 198 & 84 & 15200 & 540 & 47 & 53 \\
\hline
\end{tabular}

${ }^{1}$ All values are the means of duplicate measurements. ${ }^{2}$ All values are the means of triplicate measurements.

$\mathrm{NC}_{\mathrm{amp}}=$ total number of chains per one molecule. $\mathrm{NC}$ unit-chain $=$ total number of each unit chain $(\mathrm{A}, \mathrm{B}$ and $\mathrm{B} 2+\mathrm{B} 3)$ per molecule. Samples: $M=$ mealy, $F=$ firm, $M F=$ mealy and firm. $D P=$ Degrees of Polymerization.

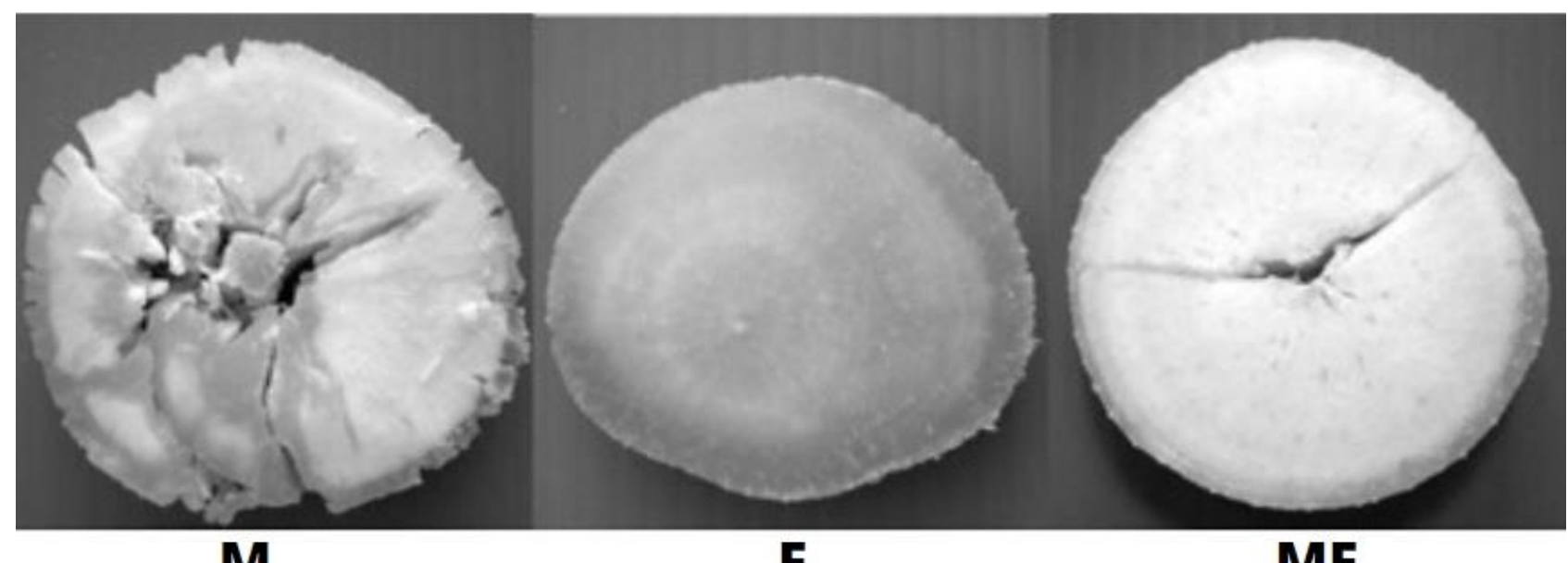

\section{M $\quad$ F $\quad$ MF}

Figure 4. Cross sections from cooked cassava roots. $M=$ mealy, $F=$ firm, $M F=$ mealy and firm (Charoenkul et al., 2006)

One of the first reports on cassava breeding was published in Brazil, in 1899. Breeders focus used was in root yield, that is correlated with several plant traits: root weight, number of roots per plant and harvest index (HI), as well as resistance to biotic or abiotic situations (Fukuda, Silva, \& Iglesias, 2002). Farmers use to select cassava cultivars based in other quality traits (taste, appearance, fiber content, and cooking time), too. So, breeders should involve them in the selection process at the early stage of breeding. This is termed participatory plant breeding (PPB) (Fialho \& Vieira, 2011; Kamau et al., 2011; Vieira et al., 2018).

The cooking time is a decisive feature in the selection of new cultivars for the purpose of cooking, because shorter cooking time spends less energy and usually generates a better pattern of mass. This review focus in methods that were used to determine cassava roots cooking time (CT).

\section{METHODS TO DETERMINE CASSAVA ROOTS COOKING TIME}

The methods to assess the texture of food can be divided into two classes: the sensory evaluation (subjective) and the instrumental (objective). The sensory one involves one person or sensory analysis panels that should be trained. Instrumental methods may be done by attaching a sample to a universal testing machine, in order to measure the amount of force required to complete a test of the mechanical properties of the tested material as well as other parameters (Blahovec, Esmir, \& Vacek, 2000).

The conception of sensory science could be considered in the 1940s, with the development of consumer or hedonic food acceptance methodologies by the US Army Corps (Peryam \& Pilgrim, 1957). However, we can trace it earlier, back to the 1800s, with the development of psychological theories to measure and predict human responses to external stimuli (Lawless \& Heymann, 1999). The panel can be trained on a few or a large number of attributes (sometimes for several hundred hours) so they will operate in unison as an instrument. Panel and panelist performance should be monitored throughout training to identify problem areas. 
Among the simplest subjective methods, we mention the one used to evaluate the degree of softening by pressing between fingers. Cassava roots were cleaned, peeled and manually sliced with stainless steel knives into cubes of about $3 \mathrm{~cm}$ (500 g for each repetition) and subjected to three cooking methods (boiling, steaming and microwave) for 25 minutes. The CT was evaluated subjectively through the pressure of cooked cassava within fingers (Lima et al., 2017; Ramírez-Cárdenas, Leonel, \& Costa, 2008).

Pedri et al. (2018) put the peeled roots in a pan, with a liter of boiling water $\left(98^{\circ} \mathrm{C}\right)$. Cooking was checked with a fork and the root was considered cooked when it no longer offered resistance to penetration. They followed a scale with four classes: optimal cooking (0 to 10 minutes); good (11 to 20 minutes); regular (21 to 30 minutes) and poor (> 30 minutes), according to Pereira, Lorenzi and Valle, (1985). Lorenzi (1994) harvested cassava roots, cut in cylinders, with about $70 \mathrm{~g}$, peeled, placed in sieves and immersed in a pan with about $20 \mathrm{~L}$ of boiling water. Each sieve represented a plant and the CT was measured at each root, using a fork to determine the ideal cooking point. Root tips showed lower CT (which can vary up to $10 \mathrm{~min}$ ). There was a wide variation in CT between roots of the same plant and roots of different plants of the same variety. Minimally processed cassava roots were subjected to cooking (50 g per $1000 \mathrm{~mL}$ of water) for approximately 20 minutes, in a stainless-steel container, until the material did not show resistance to perforation by a stainless-steel fork (Alves, Cansian, Stuart, \& Valduga, 2005).

Pieces of $5 \mathrm{~cm}$ of cassava peeled roots were placed in boiling water and, periodically, they were pricked with a fork to check the degree of cooking and to determine the CT. Correlation between starch and dry matter contents was positive $(r=0.9826)$ and correlation between starch content and cooking was negative ( $r=-0.0570$ ) (Borges, Fukuda, \& Rossetti, 2002).

Cassava roots, were peeled and washed, then put in separate polythene bags and placed in pots with water over a fire and allowed to boil for $10 \mathrm{~min}$ (Kamau et al., 2011). Water was drained, and roots were placed on labelled plates which were evaluated for palatability, one genotype at a time by 5 groups of 13 farmers, rated as follows:

(i) Appearance ( $1=$ very acceptable; $2=$ acceptable; $3=$ not acceptable).

(ii) Taste/ texture (1= sweet/mealy, $2=$ medium, $3=$ bitter/waxy).

(iii) Fiber ( $1=$ few fibers; $2=$ medium fibrous; $3=$ very fibrous).

(iv) Size (1= large/marketable; $2=$ medium; $3=$ not marketable) (rated for raw roots)

Overall acceptability of each genotype was based on the aggregate sum of raw and cooked tubers, scores as indicated below:

(i) Aggregate score of $7=$ very acceptable).

(ii) Aggregate score of 8 to $15=$ fairly acceptable).

(iii) Aggregate score of 16 to $21=$ not acceptable).

After boiling cassava roots for 40 minutes, cooking quality was done by a trained sensory evaluation panel, using a scale of 1 to 4 ( 1 =very poundable, $2=$ poundable, $3=$ fairly poundable and $4=$ not poundable) (Adjei-Nsiah \& Issaka, 2013). They concluded that with the application of organic manure, before planting, the mealiness was improved.

\section{Subjective \& Objective}

After selecting the roots, they were cleaned, cut into $3 \mathrm{~cm}$ long pieces, placed in a mass ratio of 1:10 (cassava: water) boiling water $\left(98^{\circ} \mathrm{C}\right)$. The CT was determined, in three repetitions, when they offered little resistance to penetration by a fork perpendicularly in relation to the length, being always verified by the same researcher. Cut resistance (CR) was determined in 5 to 9 repetitions, using the TA.XT Plus Texture Analyzer texturometer, operating with force measurement in compression and Warner-Bratzler Blade HDP / BSW probe, pre-test speeds of $0.2 \mathrm{~cm} . \mathrm{seg}^{-1}$, post-test and test of $0.5 \mathrm{~cm}$. seg $\mathrm{s}^{-1}$, and distance of $5 \mathrm{~cm}$. Comparing the variability for $\mathrm{CT}$ and $\mathrm{CR}$, lower coefficients of variation were observed for cooking time than for cut resistance (Talma, Almeida, Lima, Vieira, \& Bebert, 2013).

Cassava roots were cut in twenty pieces $(3.5 \mathrm{~cm}$ along the longer root axis and $2 \mathrm{~cm}$ diameter), that were weighed and then cooked in $2.5 \mathrm{~L}$ of distilled water. Final CT was defined as the minutes needed to completely soften the tissue, as determined by a trained judge (till reached score 4). The cooked samples 
were weighed and maintained at $55-60^{\circ} \mathrm{C}$, in thermal boxes, until sensory or texture analysis. Sensorial analysis was performed by 8 trained people, using a category scale with seven points $(1=\mathrm{raw} / \mathrm{hard}$ texture, 4 = optimum flavor/optimum texture, 7 = flavor of overcooked/texture pulpy) The Texture Profile Analysis (TPA) was determined in a Stable Micro System, model TA.-XT2 (Stable Micro System, Texture Technologies Corp.). TPA samples were compressed to $30 \%$ of initial height using two compression cycles with constant crosshead velocity of $2 \mathrm{~mm} \cdot \mathrm{seg}^{-1}$ using the P25 cylinder. The conclusion was that weight gain during cooking can be an indicator of cooking quality (roots considered well-cooked absorbed more than $20 \mathrm{~g} \mathrm{H}_{2} \mathrm{O}$ per 100 $\mathrm{g})$, varying from 5.4 to 33.7. Parameters of TPA that had linear variation were hardness and chewiness (Beléia et al., 2005).

\section{Instrumental (Objective)}

Destro et al. $(2003,2013)$ working with food-type soybean lines measured CT with a simple apparatus, a modified Mattson machine (Mattson, 1946). It was previously heated in a water bath, without the seeds. Then, 25 seeds were placed in individual capsules and on top of each, a rod with a needle on its tip was placed (weight $90 \mathrm{~g}$ ). The machine was then taken to a recipient containing boiling distilled water. After the fall of the 13th rod the sample was considered cooked. Coefficients of variation were 6.94 and 4.25. Cooking time had significant negative phenotypic correlation $(-0.40)$ with imbibition percentage in experiment 1 , indicating that imbibition percentage is one of the main variables that influences cooking time.

Miranda, Beleia and Fonseca-Junior (2008) planted 6 cultivars in a randomized block design with four replications. There were seven bimonthly harvests in 2 consecutive years, starting 8 months after planting. At each time 3 competitive plants of each block were harvested. Five healthy roots were selected from each harvested plant, peeled and cut in sections in their central part. The pieces were washed, drained, weighed $(80 \mathrm{~g})$, conditioned in polyethylene bags, identified, and placed in cold chamber at $5^{\circ} \mathrm{C}$, prior to their cooking in the following day. Since 3 plants per plot were harvested, 15 root pieces were used. To evaluate $\mathrm{CT}$, an adaptation of the device of Mattson used by Destro et al. (2003), was developed (Figure 5). Rods weighing $90 \mathrm{~g}$ were used. In a pan, with the separator screen, $7 \mathrm{~L}$ of de-ionized water were warmed until boiling. The pieces to be cooked were organized inside the pan, with utmost care to support the tip of the needle of each rod on of the central part of each piece of the cassava root. The cooking time was recorded after total penetration of eight needles of the rods in the roots. The coefficients of variation were extremely low ( 2 and $6.1 \%$, for each year), which indicated that the methodology used was appropriate for assessing cooking time of roots among cassava cultivars.

Rimoldi et al. (2006) employed the method used by Miranda et al. (2008), to classify 14 cassava cultivars, in 2 planting years, for CT. It was observed a variation coefficient of 4.92 and 8.56 for each year. Cultivars showed the similar CT in both years.

Oliveira, Leonel, Cabello, Cereda and Janes (2005) evaluated 26 cassava cultivars. The CT was determined with the aid of a modified Mattson device, with 24 pins of $40 \mathrm{~g}$. The roots were harvested, peeled, and cut into sticks with $10 \times 10 \times 30 \mathrm{~mm}$. They were placed in the equipment, in a pan with $7 \mathrm{~L}$ of boiling water. When 13 pins penetrated the sticks, it was considered as the CT. The water absorption \% after cooking was determined. Only 1 cultivar showed a CT less than $30 \mathrm{~min}$, with water absorption of $16.7 \%$. The other cultivars that had high absorption \% / low cooking \%: 37.1 / 37.7, 30.9 / 20, 29.9 / 23.3, 20.7 / 36.7, 19.3 / 0. These results are at odds with those obtained by Destro et al. (2003), Beléia et al. (2005), Miranda et al. (2008) and Kouadio, Nindjin, Bonfoh, N'dri and Amani (2011). Probably because the sticks are smaller than necessary, or the weight of the pins is lower, or because the sticks have been cut from random parts of the roots, instead of using the middle parts, as suggested by Lorenzi (1994) and Miranda et al. (2008).

Thirty $g$ of the central section of cassava roots were weighed and cooked in $500 \mathrm{~mL}$ of boiling water for 20 minutes. Then, were immersed in cold water for 2 minutes. Cooked and fresh pieces were dried at $70^{\circ} \mathrm{C}$ for 15 hours and then at $103^{\circ} \mathrm{C}$ for 3 hours in a vacuum oven. The cooking quality parameters (dry matter, water absorbed during cooking, soluble dry matter during cooking and water absorption capacity) were calculated per $100 \mathrm{~g}$ of raw matter. Water absorbed by mealy cooking cassava ( $27.6 \pm 8.8 \%$ ) is significantly $(p<0.05)$ higher compared to water absorbed by hard cooking cassava $(12.4 \pm 1.9 \%)$. Water absorbed during cooking is the main parameter in determining the quality of cassava cultivars (Kouadio et al., 2011), reinforcing what was observed by Beléia et al. (2005) and Destro et al. (2003), for cassava roots and soybean, respectively. 
To measure the textural characteristics of cassava dough samples, Rodríguez-Sandoval, FernándezQuintero, Sandoval-Aldana and Quicazán (2008) used TPA and stress-relaxation tests, because of the simplicity of operation and the requirement of a rather simple texture-measuring instrument and they were sufficiently sensitive to detect changes related to different processing conditions.

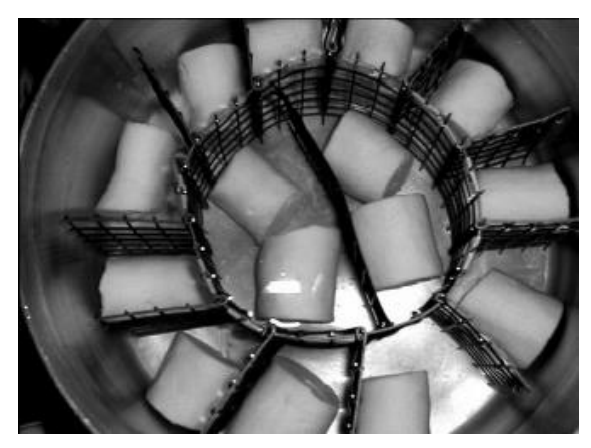

A

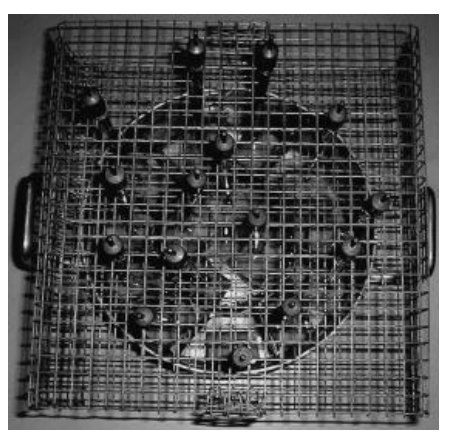

B

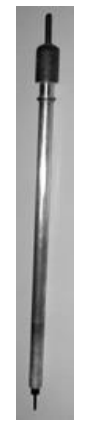

C

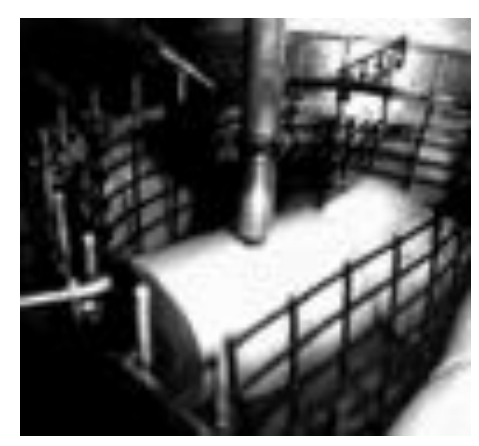

D

Figure 5. Mattson apparatus adapted to measure sweet cassava cooking time. $A=$ Cassava roots separated inside the panel, $B=$ support for the rods, $C=$ Rod, $D=$ Rod after penetration in a cooked root (Miranda et al., 2008).

\section{FINAL COMMENTS}

It is important to identify each genotype, as well as the appropriate use of each one. Differences in CT, type of starch and its swelling power, solubility, syneresis, nutritional content and digestibility, indicates the different food and non-food uses that are possible for each cultivar. Good management practices, such as weeding, proper spacing, application of suitable fertilizers, adjust soil $\mathrm{pH}$, optimal harvesting period and adequate post-harvest procedures can enhance profitability.

Several studies have found variations in sweet cassava CT in relation to the genotype, planting region, use of fertilizers, pruning the aerial part a few days before harvest, disease or pest attack, time of harvest, postharvest procedures, etc. However, only a few studies reported statistical analyses, such as the observed variation coefficient or standard deviation. And this is essential to define the best method to be employed. Other important observations are the cost and ease of application of the methodology. That is why we suggest the method applied by Rimoldi et al. (2006) and Miranda et al. (2008) and weight gain during cooking (Destro et al., 2003; Beléia et al., 2005; Kouadio et al., 2011). If the laboratory has more sophisticated devices to evaluate the texture and other parameters of the cooked root, they are certainly of great value.

Policy makers must understand the importance of cassava as a food security crop, that has the potential to double the profitability of smallholder farmers, as well as generate jobs and attract youth to participate in agriculture, reducing their migration to urban areas. So, they should construct and maintain good roads, incentive industries that use cassava as raw material, train producers with appropriate techniques and encourage family agribusiness.

\section{REFERENCES}

Adjei-Nsiah, S. (2013). Farmers' Agronomic and Social Evaluation of the Productivity, Yield and Cooking Quality of Four Cassava Varieties. American Journal of Experimental Agriculture, 3(1), $165-174$. https://doi.org/10.9734/ajea/2013/2206

Afoakwa, E. O., Asiedu, C., Budu, A. S., Chiwona-Karltun, L., Nyirendah, D. B. (2012). Chemical composition and cyanogenic potential of traditional and high yielding CMD resistant cassava (Manihot esculenta crantz) varieties. International Food Research Journal, 19(1), 175-181. Retrieved from https://www.researchgate.net/publication/255687440_Chemical_composition_and_cyanogenic_poten tial_of_traditional_and_high_yielding_CMD_resistant_cassava_Manihot_esculenta_Crantz_varieties 
Alves, A., Cansian, R. L., Stuart, G., Valduga, E. (2005). Alterações na qualidade de raízes de mandioca (Manihot esculenta Crantz) minimamente processadas. Ciência e Agrotecnologia, 29(2), 330-337. https://doi.org/https://doi.org/10.1590/S1413-70542005000200009

Alves, A. A. C., \& Setter, T. L. (2000). Response of cassava to water deficit: Leaf area growth and abscisic acid. Crop Science, 40(1), 131-137. https://doi.org/10.2135/cropsci2000.401131x

Andrade, E. C., Laranjeira, F. F. (2019). African cassava mosaic virus ( ACMV ) e a Doença do Mosaico da Mandioca ( Cassava Mosaic Disease, CMD ): Cruz das Almas, BA: Embrapa Mandioca e Fruticultura. Retrieved from https://www.infoteca.cnptia.embrapa.br/infoteca/bitstream/doc/1117975/1/Documento240EduardoC humbinhoAINFO.pdf.

Araújo, F. C. B., Moura, E. F., Cunha, R. L., Farias-Neto, J. T., Silva, R. S. (2019). Chemical root traits differentiate 'bitter' and 'sweet' cassava accessions from the Amazon. Crop Breeding and Applied Biotechnology, 19(1), 77-85. https://doi.org/10.1590/1984-70332019v19n1a11

Balagopalan, C. (2002). Cassava: Biology, Production and Utilization. In Cassava: Biology, Production and Utilization (pp. 301-318). CAB International. Retrieved from http://ciatlibrary.ciat.cgiar.org/articulos_ciat/cabi_18ch15.pdf

Beléia, A., Prudencio-ferreira, S. H., Yamashita, F., Sakamoto, T. M., Ito, L. (2004). Sensory and Instrumental Texture Analysis of. Journal of Texture Studies, 35, 542-553. https://doi.org/https://doi.org/10.1111/j.1745-4603.2004.35505.x

Beleia, A., Butarelo, S. S., \& Silva, R. S. F. (2006). Modeling of starch gelatinization during cooking of cassava (Manihot esculenta Crantz). LWT - Food Science and Technology, 39(4), 400-405. https://doi.org/10.1016/j.lwt.2005.02.021

Bertoft, E. (2017). Understanding starch structure: Recent progress. Agronomy, 7, 1-29. https://doi.org/10.3390/agronomy7030056

Blahovec, J., Esmir, A. S., Vacek, J. (2000). Objective method for determination of potato cooking. In Objective method for determination of potato cooking (Vol. 2, pp. 1-20). CIGR. Retrieved from https://cigrjournal.org/index.php/Ejounral/article/view/81/75.

Borges, M. D. F., Fukuda, W. M. G., \& Rossetti, A. G. (2002). Avaliação de variedades de mandioca para consumo humano. Pesquisa Agropecuaria Brasileira, 37(11), 1559-1565. https://doi.org/10.1590/s0100-204×2002001100006

Carvalho, L. J. C. B., Anderson, J. V, Silva, J. P., Chen, S., \& Souza, C. R. B. (2019). Protein content in cassava storage root is associated with total abundance of carotenoids. International Research Journals, 10(1), 1-10. Retrieved from https://ainfo.cnptia.embrapa.br/digital/bitstream/item/208114/1/proteincontent-in-cassava-storage-root-is-associated-with-total-abundance-of-carotenoids.pdf

Charoenkul, N., Uttapap, D., Pathipanawat, W., \& Takeda, Y. (2006). Molecular structure of starches from cassava varieties having different cooked root textures. Starch/Staerke, 58(9), 443-452. https://doi.org/10.1002/star.200600515

Chávez, A. L., Sánchez, T., Jaramillo, G., Bedoya, J. M., Echeverry, J., Bolaños, E. A., ... Iglesias, C. A. (2005). Variation of quality traits in cassava roots evaluated in landraces and improved clones. Euphytica, 143(1-2), 125-133. https://doi.org/10.1007/s10681-005-3057-2

Chisenga, S. M., Workneh, T. S., Bultosa, G., \& Alimi, B. A. (2019). Progress in research and applications of cassava flour and starch: a review. Journal of Food Science and Technology, 56(6), 2799-2813. https://doi.org/10.1007/s13197-019-03814-6 

for traits related to cooking time in soybean. Cropp Breeding and Applied Biotechnology, 3(4), 275-280. https://doi.org/10.12702/1984-7033.v03n04a05

Destro, D., Faria, A. P., Destro, T. M., Faria, R. T., Gonçalves, L. S. A., \& Lima, W. F. (2013). Food type soybean cooking time: A review. Crop Breeding and Applied Biotechnology, 13(3), 194-199. https://doi.org/10.1590/\$1984-70332013000300007

Djabou, A. S. M., Carvalho, L. J. C. B., Li, Q. X., Niemenak, N., \& Chen, S. (2017). Cassava postharvest physiological deterioration: a complex phenomenon involving calcium signaling, reactive oxygen species and programmed cell death. Acta Physiologiae Plantarum, 39(4). https://doi.org/10.1007/s11738-0172382-0

Eyinla, T. E., Maziya-Dixon, B., Alamu, O. E., \& Sanusi, R. A. (2019). Retention of Pro-Vitamin A content in products from new biofortified cassava varieties. Foods, 8(5), 1-14. https://doi.org/10.3390/foods8050177

FAO: Food and Agriculture Organization of the United Nations. (2013). Save and Grow: Cassava. FAO. Retrieved from http://www.fao.org/3/a-i3278e.pdf

FAO: Food and Agriculture Organization of the United Nations. (2018). Food Outlook - Biannual Report on Global Food Markets. Rome: FAO. Retrieved from http://www.fao.org/3/CA2320EN/ca2320en.pdf

Favaro, S. P., Beléia, A., Fonseca-Junior, N. S., \& Waldron, K. W. (2008). The roles of cell wall polymers and intracellular components in the thermal softening of cassava roots. Food Chemistry, 108(1), 220-227. https://doi.org/10.1016/j.foodchem.2007.10.070

Ferguson, M. E., Shah, T., Kulakow, P., \& Ceballos, H. (2019). A global overview of cassava genetic diversity. PLOS ONE, 14(11), 1-16. https://doi.org/10.1371/journal.pone.0224763

Fialho, J. F., Vieira, E. A. (2011). Seleção participativa de variedades de mandioca na agricultura familiar. Brasilia: Embrapa Cerrados. Retrieved from https://www.embrapa.br/documents/1354377/1743416/Seleção+Participativa+de+Variedades+de+Ma ndioca+na+Agricultura+Familiar.pdf/31855b72-e4cc-4a64-b75c-876defab73d4?version=1.0

Fukuda, W. M. G., Silva, S. O., Iglesias, C. (2002). Cassava Breeding. Crop Breeding and Applied Biotechnology, 2(4), 617-638. Retrieved from http://www.sbmp.org.br/cbab/siscbab/uploads/c8128f42-57b1-acce.pdf

Githunguri, C. M. (1995). Transformation Alimentaire du Manioc. In S. Egbe, T. A., Brauman, A., Griffon, D., Trèche (Ed.), Transformation Alimentaire $d u$ Manioc. ORSTOM. Retrieved from https://horizon.documentation.ird.fr/exl-doc/pleins_textes/pleins_textes_6/colloques1/43515.pdf

Gleadow, R. M., \& Woodrow, I. E. (2002). Constraints on the effectiveness of cyanogenic glycosides in herbivore defence. Journal of Chemical Ecology, 28(7), 1301-1313. https://doi.org/https://doi.org/10.1023/A:1016298100201

Graham, J., Traylor, J. (2019). Cyanide Toxicity. StatPearls Publishing. Retrieved from https://www.ncbi.nlm.nih.gov/books/NBK507796/

Guira, F., Some, K., Kabore, D., Sawadogo-Lingani, H., Traore, Y., \& Savadogo, A. (2017). Origins, production, and utilization of cassava in Burkina Faso, a contribution of a neglected crop to household food security. Food Science and Nutrition, 5(3), 415-423. https://doi.org/10.1002/fsn3.408 
Henrique, C. M., Prati, P., Sarmento, S. B. S. (2010). Alterações fisiológicas em raízes de mandioca minimamente processadas. In Simpósio em Ciência e Tecnologia de Alimentos (pp. 1-7). Aracaju. Retrieved from https://repositorio.usp.br/item/001822200

Iyer, S., Mattinson, D. S., \& Fellman, J. K. (2010). Study of the Early Events Leading to Cassava Root Postharvest Deterioration. Tropical Plant Biology, 3(3), 151-165. https://doi.org/10.1007/s12042-0109052-3

Jarvis, A., Ramirez-Villegas, J., Campo, B. V. H., \& Navarro-Racines, C. (2012). Is Cassava the Answer to African Climate Change Adaptation? Tropical Plant Biology, 5(1), 9-29. https://doi.org/10.1007/s12042012-9096-7

Kamau, J., Melis, R., Laing, M., Derera, J., Shanahan, P., \& Ngugi, E. C. K. (2011). Farmers ' participatory selection for early bulking cassava genotypes in semi-arid Eastern Kenya. Journal of Plant Breeding and Crop Science, 3(3), 44-52. Retrieved from https://www.researchgate.net/publication/285828947_Farmers'_participatory_selection_for_early_bul king_cassava_genotypes_in_semi-arid_Eastern_Kenya

Kouadio, O. K., Nindjin, C., Bonfoh, B., N'dri, D., \& Amani, G. N. (2011). Water absorption as an evaluation method of cooking quality for yam (Dioscorea alata) and cassava (Manihot esculenta crantz). Procedia Food Science, 1, 153-159. https://doi.org/10.1016/j.profoo.2011.09.024

Lawless, H. T., Heymann, H. (1999). Physiological and psychological foundations of sensory function. In Sensory Evaluation of Food (pp. 28-74). New York: Chapman and Hall. Retrieved from https://www.springer.com/gp/book/9781441964878

Lima, A. C. S., Viana, J. D. R., Sabino, L. B. S., Silva, L. M. R., Silva, N. K. V., Sousa, P. H. M. (2017). Processing of three different cooking methods of cassava: Effects on in vitro bioaccessibility of phenolic compounds and antioxidant activity. LWT - Food Science and Technology, 76, 253-258. https://doi.org/10.1016/j.lwt.2016.07.023

Liu, G., Li, B., Li, X., Wei, Y., Liu, D., \& Shi, H. (2019). Comparative physiological analysis of methyl jasmonate in the delay of postharvest physiological deterioration and cell oxidative damage in Cassava. Biomolecules, 9(9), 1-14. https://doi.org/10.3390/biom9090451

Lorenzi, J. O. (1994). Variação na qualidade culinária das raízes de mandioca. Bragantia, 53(2), 237-245. https://doi.org/10.1590/s0006-87051994000200013

Market Research Future. (2020). Cassava Market Global Research Report Information. Retrieved from https://www.marketresearchfuture.com/reports/cassava-market-4629

Mattson, S. (1946). The cookability of yellow peas. Acta Agriculturae Suecana, 2, 185-231. Retrieved from https://www.cabdirect.org/cabdirect/abstract/19471403040

Maxmen, A. (2019). How African scientists are improving cassava to help feed the world. Researchers in Nigeria are combining genomics and conventional breeding to improve the starchy staple crop. Nature, 565, 144-146. https://doi.org/doi: 10.1038/d41586-019-00014-2

Mcmahon, J. M., White, W. L. B., \& Sayre, R. T. (1995). Review article: Cyanogenesis in cassava (Manihot esculenta Crantz). Journal of Experimental Botany, 46(7), 731-741. https://doi.org/10.1093/jxb/46.7.731

Miranda, L. A., Beleia, A. P., Fonseca-Junior, N. (2008). Cassava Cooking Time. Gene Conserve, 7(29), 489496. Retrieved from http://www.geneconserve.pro.br/site/articles/lib/pastaup/artigo042.pdf 
Miranda, L. A., Spinosa, W. A., Destro, T. M., Souza-Junior, H., Nascimento, V. (2019). Influence of harvest time and agricultural year in yield components of table cassava cultivars. Agronomy Science and Biotechnology, 5(2), 77-88. https://doi.org/10.33158/asb.2019v5i2p77

Montagnac, J. A., Davis, C. R., \& Tanumihardjo, S. A. (2009). Nutritional value of cassava for use as a staple food and recent advances for improvement. Comprehensive Reviews in Food Science and Food Safety, 8(3), 181-194. https://doi.org/10.1111/j.1541-4337.2009.00077.x

Morante, N., Sánchez, T., Ceballos, H., Calle, F., Pérez, J. C., Egesi, C., ... Fregene, M. (2010). Tolerance to postharvest physiological deterioration in cassava roots. Crop Science, 50(4), 1333-1338. https://doi.org/10.2135/cropsci2009.11.0666

Mtunguja, M. K., Beckles, D. M., Laswai, H. S., Ndunguru, J. C., \& Sinha, N. J. (2019). Opportunities to commercialize cassava production for poverty alleviation and improved food security in Tanzania. African Journal of Food, Agriculture, Nutrition and Development, 19(1), 13928-13946. https://doi.org/10.18697/AJFAND.84.BLFB1037

Mtunguja, Mariam K., Thitisaksakul, M., Muzanila, Y. C., Wansuksri, R., Piyachomkwan, K., Laswai, H. S., ... Beckles, D. M. (2016). Assessing variation in physicochemical, structural, and functional properties of root starches from novel Tanzanian cassava (Manihot esculenta Crantz.) landraces. Starch/Staerke, 68(5-6), 514-527. https://doi.org/10.1002/star.201500179

Mufumbo, R., Baguma, Y., Kashub, S., Nuwamanya, E., Rubaihayo, P., Mukasa, S., ... Kyamanywa, S. (2011). Amylopectin molecular structure and functional properties of starch from three Ugandan cassava varieties. Journal of Plant Breeding and Crop Science, 3(9), 195-202. Retrieved from http://www.academicjournals.org/jpbcs

Narayanan, N. N., Ihemere, U., Ellery, C., \& Sayre, R. T. (2011). Overexpression of hydroxynitrile lyase in cassava roots elevates protein and free amino acids while reducing residual cyanogen levels. PLOS ONE, 6(7). https://doi.org/10.1371/journal.pone.0021996

Odoemelam, C. S., Percival, B., Ahmad, Z., Chang, M. W., Scholey, D., Burton, B., Okafor, P. N., Wilson, P. B. (2020). Characterization Of Yellow Root Cassava And Food Products: Investigation Of Cyanogenic Glycosides And Pro-Vitamin A. BioRxiv Biochemistry, 371, 1-19. https://doi.org/10.1101/2020.04.03.024224

Okogbenin, E., Setter, T. L., Ferguson, M., Mutegi, R., Ceballos, H., Olasanmi, B., \& Fregene, M. (2013). Phenotypic approaches to drought in cassava: Review. Frontiers in Physiology, 4 MAY(May), 1-15. https://doi.org/10.3389/fphys.2013.00093

Oliveira, M. A. de, Leonel, M., Cabello, C., Cereda, M. P., \& Janes, D. A. (2005). Metodologia para avaliação do tempo de cozimento e características tecnológicas associadas em diferentes cultivares de mandioca. Ciência e Agrotecnologia, 29(1), 126-133. https://doi.org/10.1590/s1413-70542005000100016

Oresegun, A., Fagbenro, O. A., Ilona, P., \& Bernard, E. (2016). Nutritional and anti-nutritional composition of cassava leaf protein concentrate from six cassava varieties for use in aqua feed. Cogent Food \& Agriculture, 2(1). https://doi.org/10.1080/23311932.2016.1147323

Otekunrin, O. A., \& Sawicka, B. (2019). Cassava, A 21 st Century Staple Crop: How can Nigeria Harness its Enormous Trade Potentials? Acta Scientific Agriculture, 3(8), 194-202. Retrieved from https://www.researchgate.net/publication/334698159_Cassava_a_21st_Century_Staple_Crop_How_ca n_Nigeria_Harness_Its_Enormous_Trade_Potentials

Pedri, E. C. M., Rossi, A. A. B., Cardoso, E. S., Tiago, A. V., Hoogerheide, E. S. S., \& Yamashita, O. M. (2018). Características morfológicas e culinárias de etnovariedades de mandioca de mesa em diferentes épocas de colheita. Brazilian Journal of Food Technology, 21(0). https://doi.org/10.1590/1981-6723.07318 
Pereira, A. S., Lorenzi, J. O., Valle, T. L. (1985). Avaliacao do tempo de cozimento e padrao de massa cozida em mandiocas de mesa. Revista Brasileira de Mandioca, 4(1), 27-32. Retrieved from http://www.bdpa.cnptia.embrapa.br/consulta/busca?b=ad\&id=633308\&biblioteca=vazio\&busca=autori a:\%22A\%22\&qFacets=autoria:\%22A\%22\&sort=\&paginacao=t\&paginaAtual=5771

Peryam, D. R., Pilgrim, F. J. (1957). Hedonic scale method of measuring food preferences. Food Technology, 11(Supplement), 9-14. Retrieved from http://www.sciepub.com/reference/161114

Popoola, J. O., Egwari, L. O., Bilewu, Y., Omonigbehin, E., Ogunlana, O. O., \& Daramola, F. (2019). Proximate analysis and SDS-PAGE protein profiling of cassava leaves: utilization as leafy vegetable in Nigeria. MOJ Ecology \& Environmental Sciences Research, 4(1), 1-5. https://doi.org/10.15406/mojes.2019.04.00125

Ramírez-Cárdenas, L., Leonel, A. J., \& Costa, N. M. B. (2008). Efeito do processamento doméstico sobre o teor de nutrientes e de fatores antinutricionais de diferentes cultivares de feijão comum. Ciencia $e$ Tecnologia de Alimentos, 28(1), 200-213. https://doi.org/10.1590/S0101-20612008000100029

Reyes, J., Snow, T., \& Rodd, T. (2018). Replacing Feed Protein with Cassava Leaf Meal ( CLM ) Protein in Weaner and Growing Pigs ' Diets. CCAMLR Science, 25(3), 253-260. Retrieved from http://www.ccamlrscience.com/index.php/ccamlrscience/article/view/247/0

Rimoldi, F., Vidigal Filho, P. S., Vidigal, M. C. G., Clemente, E., Pequeno, M. G., Miranda, L., \& Kvitschal, M. V. (2006). Produtividade, composição química e tempo de cozimento de cultivares de mandiocademesa coletadas no Estado do Paraná. Acta Scientiarum. Agronomy, 28(1), 63-69. https://doi.org/10.4025/actasciagron.v28i1.1308

Rodríguez-Sandoval, E., Fernández-Quintero, A., Sandoval-Aldana, A., Quicazán, M. C. (2007). on the Textural Properties of Cassava Dough. Journal of Texture Studies, 39(2008), 68-82. https://doi.org/https://doi.org/10.1111/j.1745-4603.2007.00131.x

Salcedo, A. (2011). Insights into the Physiological, Biochemical and Molecular Basis of Postharvest Deterioration in Cassava (Manihot esculenta) Roots. American Journal of Experimental Agriculture, 1(4), 414-431. https://doi.org/10.9734/ajea/2011/784

Sánchez, T., Chávez, A. L., Ceballos, H., Rodriguez-Amaya, D. B., Nestel, P., \& Ishitani, M. (2006). Reduction or delay of post-harvest physiological deterioration in cassava roots with higher carotenoid content. Journal of the Science of Food and Agriculture, 86(4), 634-639. https://doi.org/10.1002/jsfa.2371

Singh, S., Singh, N., Isono, N., \& Noda, T. (2010). Relationship of granule size distribution and amylopectin structure with pasting, thermal, and retrogradation properties in wheat starch. Journal of Agricultural and Food Chemistry, 58(2), 1180-1188. https://doi.org/10.1021/jf902753f

Talma, S. V., Almeida, S. B., Lima, R. M. P., Vieira, H. D., \& Bebert, P. A. (2013). Tempo de cozimento e textura de raízes de mandioca. Brazilian Journal of Food Technology, 16(2), 133-138. https://doi.org/10.1590/s1981-67232013005000016

Taylor, N. J., Fauquet, C. M., \& Tohme, J. (2012). Overview of Cassava Special Issue. Tropical Plant Biology, 5(1), 1-3. https://doi.org/10.1007/s12042-012-9098-5

Thakkar, S. K., Huo, T., Maziya-Dixon, B., \& Failla, M. L. (2009). Impact of style of processing on retention and bioaccessibility of $\beta$-carotene in cassava (Manihot esculenta, Crantz). Journal of Agricultural and Food Chemistry, 57(4), 1344-1348. https://doi.org/10.1021/jf803053d 
Valduga, E., Tomicki, L., Witschinski, F., Colet, R., Peruzzolo, M., Ceni, G. C. (2011). Avaliação da aceitabilidade e dos componentes minerais de diferentes cultivares de mandioca (Manihot esculenta Crantz) após a coç̧ão. Alimentos e Nutricao, 22(2), 205-210. Retrieved from https://biblat.unam.mx/pt/revista/alimentos-e-nutricao/articulo/avaliacao-da-aceitabilidade-e-doscomponentes-minerais-de-diferentes-cultivares-de-mandioca-manihot-esculenta-crantz-apos-a-coccao

Vasconcelos, L. M., Brito, A. C., Carmo, C. D., Oliveira, P. H. G. A., \& Oliveira, E. J. (2017). Phenotypic diversity of starch granules in cassava germplasm. Genetics and Molecular Research, 16(2), 1-15. https://doi.org/10.4238/gmr16029276

Vieira, E. A., Fialho, J. F., de Julio, L., Carvalho, L. J. C. B., Corte, J. L. D., Rinaldi, M. M., ... Anjos, J. R. N. (2018). Sweet cassava cultivars with yellow or cream root pulp developed by participatory breedin. Crop Breeding and Applied Biotechnology, 18(4), 450-454. https://doi.org/10.1590/198470332018 V18N4C67

Yeoh, H. H., \& Truong, V. Den. (1996). Protein contents, amino acid compositions and nitrogen-to-protein conversion factors for Cassava roots. Journal of the Science of Food and Agriculture, 70(1), 51-54. https://doi.org/10.1002/(SICI)1097-0010(199601)70:1<51::AID-JSFA463>3.0.CO;2-W

Yu, W., Li, H., Zou, W., Tao, K., Zhu, J., \& Gilbert, R. G. (2019). Using starch molecular fine structure to understand biosynthesis-structure-property relations. Trends in Food Science and Technology, 86, 530536. https://doi.org/10.1016/j.tifs.2018.08.003

Received: May 14, 2020.

Accepted: June 4, 2020.

Published: June 15, 2020.

English by: Tainá Miranda Destro. 